\title{
Phytochemical screening and antiviral activity of Marrubium vulgare
}

\author{
Amal Gaber Salman Fayyad ${ }^{1}$, Nazlina Ibrahim ${ }^{1^{*}}$, and Wan Ahmad Yaakob ${ }^{2}$ \\ ${ }^{1}$ School of Biosciences and Biotechnology, Faculty of Science and Technology, \\ Universiti Kebangsaan Malaysia 43600 Bangi Selangor, Malaysia. \\ ${ }^{2}$ School of Chemical Sciences and Food Technology, Faculty of Science and Technology \\ Universiti Kebangsaan Malaysia, 43600 Bangi Selangor, Malaysia. \\ Email: nazlina@ukm.my
}

\begin{abstract}
Aims: The present study is to investigate the phytochemical content, cytotoxicity and antiviral activity of the crude and fractions from Marrubium vulgare.

Methodology and results: The crude methanol extract and fractions using hexane, chloroform, ethyl acetate and $n$ butanol of M. vulgare whole plant were produced in this study. Qualitative phytochemical analysis revealed the presence of flavones aglycones and steroid in all preparations except for the hexane fraction. Carbohydrates, saponins were found present in the crude and ethyl acetate extracts while tannin was detected in the crude, ethyl acetate and butanol extracts. Anthraquinones and terpenes were detected in the hexane fraction. The cytotoxicity of the crude and fractions were examined using a modified MTT assay and the cell concentration that causes $50 \%$ of cell death $\left(\mathrm{CC}_{50}\right)$ was determined. The crude extract and fractions showed no toxicity towards Vero cells with the $\mathrm{CC}_{50}$ value ranges between 140 to $400 \mu \mathrm{g} / \mathrm{mL}$. Antiviral activity against herpes simplex virus type-1 (HSV-1), attachment and virus yield reduction assays were analyzed by plaque reduction assay. Only the crude extract, hexane and chloroform fractions showed antiviral activity with the selectivity indices of 3.11, 2.8 and 1.28 respectively. In this study it is revealed that the hexane fraction disrupts the early steps of cyclic replication, including HSV-1 attachment in a dose-dependent manner.

Conclusion, significance and impact of study: The crude, hexane and chloroform fractions of $M$. vulgare were not cytotoxic and have antiviral properties. Treatment with the hexane fraction inhibits viral attachment and reduces virus yield. Further study on the mechanism of $M$. vulgare must be elucidated for the potential as antiviral agent.
\end{abstract}

Keywords: Marrubium vulgare, phytochemical constituent, cytotoxicity, antiviral activity

\section{INTRODUCTION}

Acute and recurrent herpes simplex virus type 1 (HSV-1) infections remain an important problem due to the emergence of acyclovir (ACV) resistant virus that makes the search for novel antiviral substances imperative. Potential anti-herpes activity of bioactive compounds from numerous plant species have been investigated (Allahverdiyev et al., 2004; Verma et al., 2008). HSV-1 is a DNA virus that causes a variety of diseases in humans. In some instances, HSV-1 is a major threat to immunecompromised patients (Serkedjieva et al., 1999; Chuanasa et al., 2008). The present study thus sought to screen a medicinal plant, Marrubium vulgare for the safety and potential in anti-virus therapy. $M$. vulgare grows in the wild and commonly known as "Horehound" belongs to the Lamiaceae family (Masoodi et al., 2008). It has been used in folk medicine and reported to possess a wide range of biological activities and pharmacological properties. This plant has been previously reported to have antihypertensive activity (El-Baradai et al., 2004), exhibiting vasorelaxant (El-Baradai et al., 2003a; 2003b), anti-diabetic (Elberry et al., 2011; Boudjelal et al., 2012), anti-oxidant (Kadri et al., 2011), anti-inflammatory, analgesic, anti-bacterial (Masoodi et al., 2008; Kanyonga et al., 2011) and antioedematogenic (Stulzer et al., 2006) activities. However, bibliographic searches reveal that there is a dearth of information on its antiviral activity against HSV-1. In this study, various fractions of the $M$. vulgare were determined for their phytochemical constituents. The cytotoxicity and antiviral activity against HSV-1 evaluated for the crude and fractions to determine the potential as antiviral agents. The viral attachment and virus yield assays carried out for the hexane fraction to determine the preliminary mode of action.

\section{MATERIALS AND METHODS}

\section{Plant extraction}

The powder of the whole plant (including root, stem, leaves, flowers and seeds) of $M$. vulgare was purchased from Alibaba Company (Hong Kong, China). The crude extract was prepared following the method of Masoodi et

\section{${ }^{*}$ Corresponding author}


al. (2008) with minor modification. The powder of the whole plant $(50 \mathrm{~g})$ was filled in the thimble of Soxhlet apparatus and extracted with methanol for up to $9 \mathrm{~h}$. Thereafter, it was filtered and the filtrate was centrifuged at $4000 \mathrm{rpm}$ for $15 \mathrm{~min}$. The supernatant was collected and the solvent was concentrated and dried by rotary evaporator and kept at $4{ }^{\circ} \mathrm{C}$ until used.

Plant fractions were prepared following the method of llango et al. (2009) and Ramkumar et al. (2007) with slight modifications. Dried powder $(200 \mathrm{~g})$ was dispensed in the thimble of a Soxhlet apparatus and extracted with distilled water and methanol (1:2) for up to $15 \mathrm{~h}$. The methanol from the resulting extract was removed by rotary evaporation and the liquid part successively partitioned $(3 \times 50 \mathrm{~mL})$ with hexane, chloroform, ethyl acetate and $n$ butanol yielding four fractions. These fractions were filtered and concentrated under reduced pressure. Subsequently, the obtained aqueous fraction was lyophilized.

\section{Phytochemical analysis}

Phytochemical analysis of the crude extract and four fractions was established according to standard procedures used to test for the presence of alkaloids, carbohydrates, saponins, tannins, flavones glycones, steroids, terpenes and anthraquinone as described by Kasolo et al. (2010) and Edeoga et al. (2005).

\section{Cells and virus}

Vero cell lines from the stock collection of the Virology Laboratory, School of Biosciences and Biotechnology were grown in Dulbecco's Modified Eagle Medium (DMEM) supplemented with $5 \%$ fetal bovine serum, penicillin/streptomycin (100 U/L) and non-essential amino acids. Cell culture was maintained at $37{ }^{\circ} \mathrm{C}$ under a humidified $5 \% \mathrm{CO}_{2}$ atmosphere. A clinical isolate of HSV1 was propagated in Vero cells and incubated at $37^{\circ} \mathrm{C}$ until the cytopathic effect develops. The titer of virus was estimated and stored at $-80^{\circ} \mathrm{C}$ until used.

\section{Cytotoxicity assay}

Evaluation on the crude and fraction cytotoxicity towards Vero cells was performed using MTT [3-(4,5dimethylthiazol-2-yl) -2,5-diphenyl tetrazolium bromide] assay. Vero cells $\left(2 \times 10^{5}\right.$ cells $\left./ \mathrm{mL}\right)$ were prepared in 96 well tissue culture plates, after a $24 \mathrm{~h}$ period of incubation at $37{ }^{\circ} \mathrm{C}$ under a humidified $5 \% \mathrm{CO}_{2}$ atmosphere. The medium was removed from the wells, and $100 \mu \mathrm{L}$ of dilutions of the crude extract and fractions $(70 \mu \mathrm{g} / \mathrm{mL}$ to $600 \mu \mathrm{g} / \mathrm{mL}$ concentration prepared in cell culture medium) were added to each well. Control cells were added with only $100 \mu \mathrm{L}$ of the medium. The plates were incubated for 3 days under the same conditions mentioned above. Subsequently, the medium was removed and the cells washed by phosphate buffer saline (PBS) followed by the addition of $100 \mu \mathrm{L}$ of DMEM and $10 \mu \mathrm{L}$ of MTT to each well. The plates were then incubated for $3 \mathrm{~h}$. The MTT solution was then removed and $130 \mu \mathrm{L}$ of dimethyl sulfoxide (DMSO) was added to each well to dissolve the formazan crystals, followed by gentle shaking for $15 \mathrm{~min}$. Absorbance was determined spectrophotometrically on a multi-well plate reader at $540 \mathrm{~nm}$. The $\mathrm{CC}_{50}$ was defined as the cytotoxic concentration of each extract that reduced the absorbance of treated cells to $50 \%$ when compared with that of the control cells (Akanitapichat et al., 2005; Capua et al., 2010). CC $_{50}$ values were calculated using regression analysis.

\section{Antiviral activity}

Vero cell line $\left(2 \times 10^{5}\right.$ cells $\left./ \mathrm{mL}\right)$ was prepared in 24 wells (500 $\mu \mathrm{L}$ in each well). When the cells is $80-90 \%$ confluent, the medium was removed from the wells. HSV-1 at 50 pfu and DMEM were added subsequently to the cells and incubated for $1 \mathrm{~h}$. The medium was removed and different concentrations of crude extract and fractions (concentration is less than the $\mathrm{CC}_{50}$ values) were added to the methyl cellulose (MC) which was applied to the cells. This was then incubated for two days. After the plaques appeared, the plates were stained with crystal violet and shaken for about $30 \mathrm{~min}$, followed by gentle washing. The plates were left to dry and the number of plaques was counted using an inverted microscope. The $I_{50}$ was defined as the concentration of the extracts that inhibit $50 \%$ of the plaques in virus infected cells compared to control (Yew et al., 2002). The mean number of plaques was used to calculate the percentage of plaques inhibited. A curve relating percent plaque inhibition against extract concentrations was used to calculate the inhibitory concentration that elucidated a $50 \%$ reduction of cell viability $\left(\mathrm{IC}_{50}\right)$. The experiments were performed in triplicates with the mean values represent three experiments

\section{Attachment assay}

This assay was carried out by mixing virus and the hexane fraction with different concentrations and incubated at room temperature one minute. Vero cell monolayer was grown in 12 well culture plate and then pre-chilled at $4{ }^{\circ} \mathrm{C}$ for $1 \mathrm{~h}$. The medium was aspirated and the cell monolayer was infected with 100 a plaque-forming unit (PFU)/well of HSV-1 in the absence or presence of different concentrations of hexane fraction, then incubated at $4{ }^{\circ} \mathrm{C}$ for another $3 \mathrm{~h}$. The medium was aspirated to remove virus inoculum and cell monolayer was washed with PBS and overlaid with medium containing 1\% methylcellulose. The cell monolayer was incubated for a further $48 \mathrm{~h}$ before it was fixed and stained. The percentage inhibition was calculated by the following formula:

Percentage inhibition $=$

1 - (Average number of plaques) test $_{\text {(Average }} \times 100 \%$ (Average number of plaques) control 


\section{Virus yield reduction assay}

Monolayers of Vero cells grown in 12 well plates were infected with 100 pfu/well of HSV-1 for $2 \mathrm{~h}$ at $37^{\circ} \mathrm{C}$ in $5 \%$ $\mathrm{CO}_{2}$. The inoculum was removed and hexane fraction at concentrations $20-100 \mu \mathrm{g} / \mathrm{mL}$ in DMEM with $5 \% \mathrm{FBS}$ was added. At $30 \mathrm{~h}$ after viral infection, the infected cells were lysed by freezing and thawing three times. The supernatant was obtained by centrifugation at $3000 \mathrm{rpm}$ for $10 \mathrm{~min}$ at $4{ }^{\circ} \mathrm{C}$. A serial dilution of each supernatant was prepared in DMEM and the surviving virus titer was determined by the plaque assay (Saddi et al., .2007)

\section{RESULTS AND DISCUSSIONS}

\section{Phytochemical content}

The presence of active compounds from different fractions of $M$. vulgare is shown Table 1. Carbohydrates, saponins, tannins, flavones aglycones and steroids were present in crude and ethyl acetate fractions. Alkaloids were absent in all extract and fractions. Herbs in the Family Lamiaceae have a long history of treating diverse diseases. Natural compounds purified from these herbs have demonstrated inhibitory effects on HSV-1 replication, targeting nearly every stage of the HSV-1 life cycle (Pushpa et al., 2013). These compounds vary in chemical composition and include alkaloids, polysaccharides, polyphenolics, flavonoids, coumarines, phenolics, tannins, carvacrol, triterpenes and anthraquinones. Abadi et al. (2013) and Verma et al. (2012) reported that $M$. vulgar essential oils contains major components including tetramethyl heptadecan-4-olid, germacrene d-4-ol, $\alpha$ - pinéne, phytol, dehydro-sabina ketone, piperitone, $\delta$-cadinene, 1-octen3-ol and benzaldehyde. Terpene compounds isolated from the oils includes linalool, 1-8-cineole, thymol, marrubiin (Zawislak, 2012).

In this study, the methanol crude extract of $M$. vulgare showed the highest level of inhibitory effect on HSV-1 followed by the hexane fraction. Phytochemical analysis showed that the crude and the hexane fraction contain compounds of terpenes and anthraquanins. According to Astani et al. (2011), sesquiterpenes were able to suppress viral infection by $40-98 \%$ and directly inactivate herpes virus by interfering with virion envelope structures or mask viral structures that are necessary for adsorption or entry into host cells. Soares et al. (2012) also identified the meroditerpenoid atomaric acid from the Stypopodium zonale extracts as anti-HSV-1. According to Aref et al. (2011) triterpenes showed activity against HSV-1 and their mode of action was found at all stages of multiplication. Sydiskis et al. (1991) demonstrated that the anthraquinones acted directly on the envelope of HSV-1, resulting in the prevention of virus adsorption and subsequent replication.

Table 1: Phytochemical screening of the crude and fractions of Marrubium vulgare.

\begin{tabular}{|c|c|c|c|c|c|c|c|c|}
\hline Test Sample & Carbohydrates & Alkaloids & Saponins & Tannins & $\begin{array}{l}\text { Flavones } \\
\text { aglycones }\end{array}$ & Steroids & Anthraquinone & Terpenes \\
\hline $\begin{array}{l}\text { Crude } \\
\text { Hexane }\end{array}$ & + & - & + & + & + & + & + & + \\
\hline $\begin{array}{l}\text { fraction } \\
\text { Chloroform }\end{array}$ & - & - & - & - & - & - & + & + \\
\hline fraction & - & - & - & - & + & + & - & - \\
\hline $\begin{array}{l}\text { Ethyle acetate } \\
\text { fraction }\end{array}$ & + & - & + & + & + & + & - & - \\
\hline $\begin{array}{l}n \text {-butanol } \\
\text { fraction }\end{array}$ & - & - & - & + & + & + & - & - \\
\hline
\end{tabular}

+ , present; -, absent

\section{Cytotoxicity}

Table 2 shows the $\mathrm{CC}_{50}$ values of the crude extract and the fractions towards Vero with the value of more than 20 $\mu \mathrm{g} / \mathrm{mL}$ indicating that the samples were non cytotoxic (Moo-Puc et al., 2009; Chandrashekar et al., 2011). Thus, the antiviral activity is now worth to be demonstrated for the potential as antiviral agents.

\section{Antiviral activity}

Hexane fraction displayed antiviral activity compared to other fractions as $80 \%$ of inhibition was achieved at 100 $\mu \mathrm{g} / \mathrm{mL}$ and an associated $\mathrm{IC}_{50}$ value of $50 \mu \mathrm{g} / \mathrm{mL}$ (Table 2 ). Both crude extract and chloroform fraction indicated a reduction in the number of plaques by $72 \%$ and $55 \%$ at $150 \mu \mathrm{g} / \mathrm{mL}$ and $\mathrm{IC}_{50}$ values respectively being $90 \mu \mathrm{g} / \mathrm{mL}$ and $140 \mu \mathrm{g} / \mathrm{mL}$. On the other hand, no activity was detected in the ethyl acetate or $n$-butanol fractions. The selective index (SI) was determined to associate the cytotoxicity and the antiviral potential of the tested crude and fractions as shown in Table 2 . In this study, only the crude extract, hexane fraction and chloroform fraction displayed safe antiviral activity. The effective concentrations of crude, hexane, chloroform fractions were $150 \mu \mathrm{g} / \mathrm{mL}, 100 \mu \mathrm{g} / \mathrm{mL}$ and $150 \mu \mathrm{g} / \mathrm{mL}$ respectively. We isolated the pure compound and tested for antiviral activity (data not shown). However, when compared with the methanolic crude of the whole plant, chloroform and hexane fractions in the cytotoxicity assay, it was found to be less active in antiviral activity with the selective indices was less than 2 (1.7). Thus in this study, we continue to evaluate the fraction with selective index more than 2 and higher (Aschenbrenner and Venable, 2009). 
Table 2: Cytotoxicity $\left(\mathrm{CC}_{50}\right)$, inhibition concentration $\left(\mathrm{IC}_{50}\right)$ and selective index (SI) of crude and fractions of Marrubium vulgare.

\begin{tabular}{llll}
\hline Test sample & $\mathrm{CC}_{50}$ & $\mathrm{IC}_{50}$ & $\mathrm{SI}$ \\
\hline Crude extract & $280 \mu \mathrm{g} / \mathrm{mL}$ & $90 \mu \mathrm{g} / \mathrm{mL}$ & 3.11 \\
Hexane & $140 \mu \mathrm{g} / \mathrm{mL}$ & $50 \mu \mathrm{g} / \mathrm{mL}$ & 2.8 \\
Chloroform & $180 \mu \mathrm{g} / \mathrm{mL}$ & $140 \mu \mathrm{g} / \mathrm{mL}$ & 1.28 \\
Ethyl acetate & $400 \mu \mathrm{g} / \mathrm{mL}$ & $\mathrm{NI}$ & $\mathrm{ND}$ \\
$n$-butanol & $350 \mu \mathrm{g} / \mathrm{mL}$ & $\mathrm{NI}$ & $\mathrm{ND}$ \\
\hline
\end{tabular}

$\mathrm{NI}$, No inhibition in plaque reduction assay

ND, Not determined

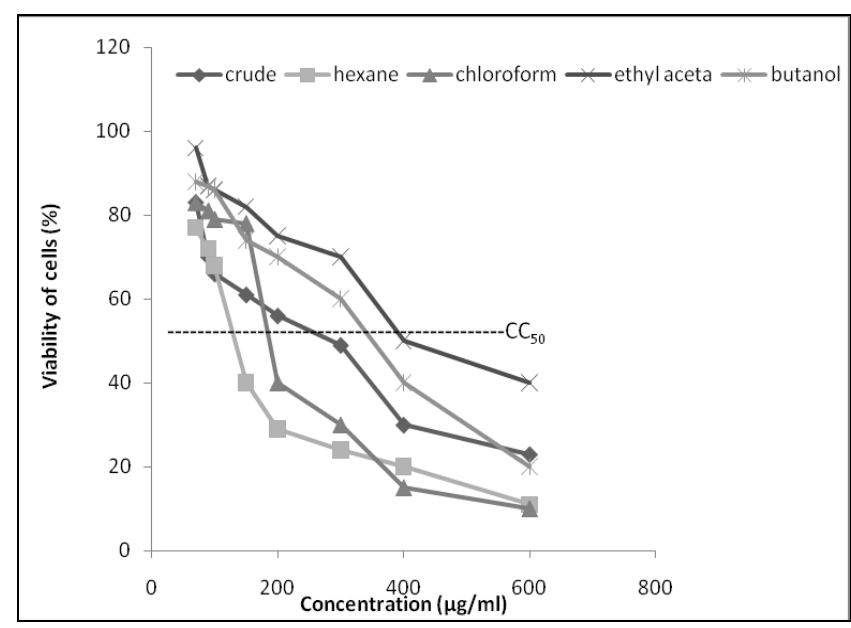

Figure 1: Viability of cells of crude and fractions of Marrubium vulgare.

In this study, the selective index or SI of crude, hexane and chloroform fractions were more than 1 thus can be accepted and at least not dangerous. For use as topical agents, drugs should not have SI less than 1. Most drugs have a selective index of 2 or higher. Drugs with SI of 5 or 10 are safer drugs (Aschenbrenner and Venable 2009; Omonike et al., 2013).

The hexane fraction was effective when it was added in parallel with the virus to cells. This observation suggests that the hexane fraction might disrupt the early steps of cyclic replication, including obstruction of viral attachment. HSV-1 attachment was inhibited by hexane fraction in a dose-dependent manner at $100 \mu \mathrm{g} / \mathrm{mL}, 90$ $\mu \mathrm{g} / \mathrm{mL}$ and $80 \mu \mathrm{g} / \mathrm{mL}$ with the percentage of inhibition was $44 \%, 33 \%$ and $18 \%$ respectively.

The complete HSV-1 replication cycle takes approximately 18 to $20 \mathrm{~h}$ (Bacon et al., 1996) but in this study the replication cycle takes place in $30 \mathrm{~h}$. Figure 2 shows the virus yields of HSV-1 in Vero cells as control or treated with varying concentrations of hexane fraction. Hexane fraction reduced the virus yields in a dose dependent manner. The highest concentration of 100 $\mu \mathrm{g} / \mathrm{mL}$ reduced the yields to less than $1 \times 10^{2} \mathrm{pfu} / \mathrm{mL}$. A $90 \mu \mathrm{g} / \mathrm{mL}$, the fraction reduced the virus yields to $2.4 \times 10^{2}$ $\mathrm{pfu} / \mathrm{mL}$ and at $80 \mu \mathrm{g} / \mathrm{mL}$ the virus yield was reduced to the half amount estimated in control cells.
Antiviral activities of some Lamiaceae species have been reported in previous studies. The extract of Thymus vulgaris has been reported to show high level of antiviral activity against HSV-1 and HSV-2 (Behravan et al., 2011). Several compounds such as carvacrol, thymol, anthraquinones, especially the polyphenolics, polysulphonates and monoterpenes derived from Lamiaceae have been shown to possess antimicrobial or antiviral activity. Most extracts exhibit their effects on viral particles prior to attachment to host cell or post-infection of the cell. Flavonoids exhibit antiviral effects via inhibiting the RNA synthesis of viruses and polyphenols act principally by binding to the protein coat, thus preventing absorption of the virus (Esimone et al., 2007; Behravan et al., 2011). In the study conducted by Amoros et al. (1987), saponin isolated from the Anagallis arvensis plant was reported to inhibit adhesion and penetration of HSV-1 to Vero cell. In another study, conducted by AndrighettiFrohner et al. (2005) plants from Brazilian tropical forest demonstrate anti-herpetic effect possibly due to their flavonoids content, especially biflavones and glycosylflavones.

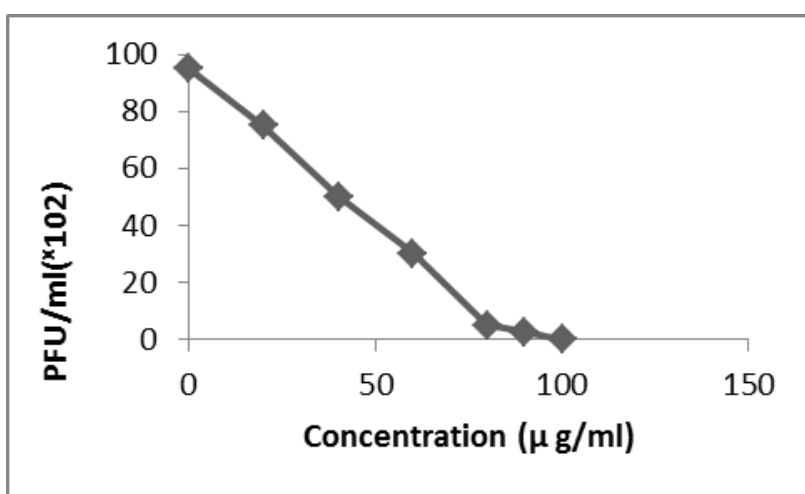

Figure 2: The yield reduction assay with hexane fraction. The inhibition in the yield of the virus significantly $(p<$ 0.05 ) at 100,90 , and $80 \mu \mathrm{g} / \mathrm{mL}$.

Hsiang and Ho (2008) investigated the action of emodin on HSV-1, the result indicated that the emodin possesses antiviral activities via the inhibition both UL12 and CK2 and disruption of the phospholipid bilayer of the envelope. A study carried out by Zandi et al. (2007) revealed that hot glycerine Aloe vera extract which contains anthraquanins could be a good choice for preventing of virus adsorption, attachment or entry to the host cell. Cohen et al. (1996) reported that the most active anthraquinone was 5,7-dichloroemodin against HSV-1 compared to $(2,6-8,13)$ anthraquinones. Further confirmation on the active compounds available in $M$. vulgare however, needs to be done in the future.

In summary, our findings suggest that $M$. vulgare contains antiviral active compounds especially in the crude extract and hexane fraction. This set the stage for future studies on the plant for the development of topical agents against HSV-1. In doing so, the mechanism of 
action of the active compound from this plant is worthy to be determined. Furthermore, the compound which is responsible to work singly or synergistically in their contribution to disintegrate the envelope of the virus must be determined.

\section{ACKNOWLEDGMENTS}

This work was supported by Universiti Kebangsaan Malaysia (BKBP-FST-K006401) and DPP-2013-022.

\section{REFERENCES}

Abadi, A. and Hassani, A. (2013). Chemical composition of Marrubium vulgare L. essential oil from Algeria. International Letters of Chemistry, Physics and Astronomy 8(3), 210-214.

Akanitapichat, P., Wangmaneerat, A., Wilairat, P. and Bastow, K. (2005). Anti-herpes virus activity of Dunbariabella prain. Journal of Ethnopharmacology 105, 64-68.

Allahverdiyev, A., Duran, N., Ozguven, M. and Koltas, S. (2004). Antiviral activity of the volatile oils of Melissa officinalis $L$. against Herpes simplex virus type-2. Phytomedicine 11, 657-661.

Amoros, M., Fauconnier, B. and Girre, R. (1987). In vitro antiviral activity of a saponin from Anagalis arvensis, Primulaceae, against herpes simplex virus and poliovirus. Antiviral Research 8, 13-25.

Andrighetti-Fröhner, C. R., Sincero, T. C. M., da Silva, A. C., Savi, L. A., Gaido, C. M., Bettega, J. M. R., Mancini, M., de Almeida, M. T. R., Barbosa, R. A., Farias, M. R., Barardi, C. R. M. and Simoes, C. M. O. (2005). Antiviral evaluation of plants from Brazilian Atlantic tropical forest. Fitoterapia 76, 374-378.

Aref, H. L., Auoni, R. M., Chaumon, J. P., Said, K. and Fekih, A. (2011). In vitro antiviral activities of Jrani caprifig latex and its related terpenes. African Journal of Microbiology Research 5(32), 5812-5818.

Aschenbrenner, D. S. and Venable, S. J. (2009). Drug Therapy in Nursing Lippincott, Williams and Wilkins. Philadelphia. pp. 52-53.

Astani, A., Reichling, J. and Schnitzler, P. (2011). Screening for antiviral activities of isolated compounds from essential oils. Evid Based Complement Alternat Med, vol. 2011, Article ID 253643,8 pages, doi: 10.1093/ $2011 / 253643$

Bacon, T. H., Howard, B. A., Spenderf, L. S. and. Boyd, M. R. (1996). Activity of penciclovir in antiviral assays against herpes simplex virus. Journal of Antimicrobial Chemotherapy 37, 303-313.

Behravan, J., Ramezani, M., Nobandegani, E and Gharaee, M. (2011). Antiviral and antimicrobial activity of Thymus transcaspicus essential oil. Pharmacologyonline 1, 1190-1199.

Boudjelal, A., Henchiri, C., Siracusa, L., Sari, M. and Ruberto, G. (2012). Compositional analysis and in vivo anti-diabetic activity of wild Algerian Marrubium vulgare L. infusion. Fitoterapia 83, 286-292.
Capua, C. J., Hopson, N. P., Stewart, M. M., Johnston G. R., O'Neill, K. L., Schaalje, G. B., Lee, C. M., and Booth, G. M. (2010). Cytotoxicity of Atriplex confertifolia. Journal of Toxicology (Article ID 2010:976548, 7 pages doi:10.1155/2010/976548).

Chandrashekar, G. J., Gopal, M. and Byregowda, S.M., (2011). Cytotoxic activity of Tragia involucrata. Linn. extracts. American-Eurasian Journal of Toxicological Sciences 3(2), 67-69.

Chuanasa, T., Phromjai, J., Lipipun, V., Likhitwitayawuid, K., Suzuki, M., Pramyothin, P., Hattori, M. and Shiraki, K. (2008). Anti-herpes simplex virus (HSV-1) activity of oxyresveratrol derived from Thai medicinal plant: Mechanism of action and therapeutic efficacy on cutaneous HSV-1 infection in mice. Antiviral Research 80, 62-70.

Cohen, P. A., Hudson, J. B. and Towers, G. H. N. (1996). Antiviral activities of anthraquinones, bianthrones and hypericin derivatives from lichens. Cellular and Molecular Life Sciences 52(2), 180-183.

Edeoga, H., Okwu, D. and Mbaebie, B. (2005). Phytochemical constituents of some Nigerian medicinal plants. African Journal of Biotechnology 4, 685-688.

El-Baradai, S., Morel, N., Wibo, M., Fabre, N., Liabres, G., Lyoussi, B. and Quetin-Leclercg, J. (2003a). The vasorelaxant activity of marrubenol and marrubiin from Marrubium vulgare. Planta Medica 69, 75-77.

El-Baradai, S., Wibo, M., Hamaide, M., Lyoussi, B., Quetin-Leclercq, J. and Morel, N. (2003b). Characterisation of marrubenol, a diterpene extracted from Marrubium vulgare, as an L-type calcium channel blocker. British Journal of Pharmacology 140, 12111216.

El-Baradai, S., Lyoussi, B., Wibo, M. and Morel, N. (2004). Comparative study of the antihypertensive activity of Marrubium vulgare and of the dihydropyridine calcium antagonist amLodipine in spontaneously hypertensive rat. Clinical and Experimental Hypertension 26, 465-474.

Elberry, A., Harraz, F., Ghareib, S., Gabr, S., Nagy, A. and Abdel-Sattar, E. (2011). Methanolic extract of Marrubium vulgare ameliorates hyperglycemia and dyslipidemia in streptozotocin-induced diabetic rats. International Journal of Diabetes Mellitus. doi:10.1016/J.ijdm.:2011.01.004.

Esimone, C. O., Ofokansi, K. C., Adikwu, M. U., Ibezim, E. C., Abonyi, D. O., Odaibo, G. N. and Olaleye, D. O. (2007). In vitro evaluation of the antiviral activity of extracts from the lichen Parmelia perlata (L.) Ach. against three RNA viruses. Infection in Developing Countries 1, 315-320.

llango, K., Chitra, V., Kanimozhi, P. and Balaji, G (2009). Antidiabetic, antioxidant and antibacterial activities of leaf extracts of Adhatoda zeylanica. Medic (Acanthaceae). Journal of Pharmaceutical Sciences and Research 1, 67-73.

Hsiang, C. Y. and Ho, T-Y.(2008). Emodin is a novel alkaline nuclease inhibitor that suppresses herpes 
simplex virus type 1 yields in cell cultures. British Journal of Pharmacology 155, 227-235.

Kadri, A., Zarai, Z., Bekir, A., Gharsallah, N., Damak, M. and Gdoura, R. (2011). Chemical composition and antioxidant activity of Marrubium vulgare L. essential oil from Tunisia. African Journal of Biotechnology 10, 3908-3914.

Kanyonga, P., Faouzi, M., Meddah, B., Mpona, M., Essassi, E. and Cherrah, Y. (2011). Assessment of methanolic extract of Marrubium vulgare for antiinflammatory, analgesic and antimicrobiologic activities. Journal of Chemical and Pharmaceutical Research 3, 199-204.

Kasolo, J., Bimeny, G., Ojok, L., Ochieng, J. and Ogwal-Okeng, J. (2010). Phytochemicals and uses of Moringa oleifera leaves in Ugandan rural communities. Journal of Medicinal Plants Research 4, 753-757.

Masoodi, M., Ahmed, B. Zargar, I., Khan, S., Khan, S., Singh, P. (2008). Antibacterial activity of whole plant extract of Marrubium vulgare. African Journal of Biotechnology 7, 86-87.

Moo-Puc, R., Robledo, D.and Freile-Pelegrín, Y. (2009). In vitro cytotoxic and antiproliferative activities of marine macroalgae from Yucatán, Mexico. Ciencias Marinas 35(4), 345-358.

Pushpa, R., Nishant, R., Navin, K. and Pankaj, G. (2013). Antiviral potential of medicinal plants: An overview. International Research Journal Pharmacy 4 (6). doi 10.7897/2230-8407/.04603.

Ramkumar, K., Rajaguru, P. and Ananthan, R. (2007). Antimicrobial properties and phytochemical constituents of an antidiabetic plant Gymnema montanum. Advances in Biological Research 1, 67-71.

Omonike, O. O., Adeniji, J. Adekunle, A. J., Edith, A. O. and Festus, A., O. (2013). Anti-poliovirus activity of medicinal plants selected from the Nigerian ethnomedicine. African Journal of Biotechnology 12(24), 3878-3883.

Sabry, R., Salama, A. B. and Sharaf-Eldin M. (2011). Growth, yield and essential oil content of Marrubium vulgare as affected by three levels of nitrogen fertilizer. Planta Medica. 77: DOI: 10.1055/s-0031-1282321.

Saddi, M., Sanna, A., Cottiglia, F., Chisu, L., Casu, L., Bonsignore, L. and De Logu, A. (2007). Antiherpevirus activity of Artemisia arborescens essential oil and inhibition of lateral diffusion in Vero cells. Annals of Clinical Microbiology and Antimicrobials doi:10.1186/2007/1476

Serkedjieva, J. and Ivancheva, S. (1999). Antiherpes virus activity of extracts from the medicinal plant Geranium sanguineum L. Journal of Ethnopharmacology 64, 59-68.

Soares, A. R., Robaina, M. C. S., Mendes, G. S., Silva, T. S. L., Gestinari, L. M. S., Pamplona, O. S., Valentin, Y. Y., Carlos R., Kaiser, C. R. and Romanos, M. T. V. (2012). Antiviral activity of extracts from Brazilian seaweeds against herpes simplex virus. Brazilian Journal of Pharmacognosy 22 (4), 714-723.

Stulzer, H. K., Tagliari, M. P., Zampirolo, J. A., Cechinel-Filho, V. and Schlemper, V. (2006).
Antioedematogenic effect of marrubiin obtained from Marrubium vulgare. Journal of Ethnopharmacology 108, 379-384.

Sydiskis, R. J., Owen, D. G., Lohr, J. L., Rosler, K.,H. and Blomster, R., N. (1991). Inactivation of enveloped viruses by anthraquinones extracted from plants. Antimicrobial Agents and Chemotherapy 35(12), 24632466.

Verma, H., Patil, P. R., Kolhapure, R. M. and Gopalkrishna, V. (2008). Antiviral activity of the Indian medicinal plant extract, Swertia chirata against herpes simplex viruses: a study by in vitro and molecular approach. Indian Journal of Medical Microbiology 26, 322-326.

Verma, A., Masoodi, M. and Ahmed, B. (2012). Lead finding from whole plant of Marrubium vulgare $\mathrm{L}$. with hepatoprotective potentials through in silico methods. Asian Pacific Journal of Tropical Biomedicine. 1, 13081311.

Yew, C. H., Ching, L. C. and Chen L. T. (2002). Antiviral properties of prodelphinidin B-2 3'-O-gallate from green tea leaf. Antiviral Chemistry and Chemotherapy 13(4), 223-229.

Zandi, K. Zadeh, M-A. Sartavi, K. and Rastian, Z. (2007). Antiviral activity of Aloe vera against herpes simplex virus type 2: An in vitro study. African Journal of Biotechnology 6(15), 1770-1773.

Zawislak, G. (2012). Chemical composition of essential oils of Marrubium vulgare $\mathrm{L}$. and Marrubium incanum desr. grown in Poland. Chemija 23(2), 136-140. 